\title{
Ex post damage assessment: an Italian experience
}

\author{
D. Molinari ${ }^{1}$, S. Menoni ${ }^{2}$, G. T. Aronica ${ }^{3}$, F. Ballio ${ }^{1}$, N. Berni ${ }^{4}$, C. Pandolfo $^{4}$, M. Stelluti ${ }^{4}$, and G. Minucci ${ }^{2}$ \\ ${ }^{1}$ Politecnico di Milano, Dept. of Environmental and Civil Engineering, Milan, Italy \\ ${ }^{2}$ Politecnico di Milano, Dept. of Planning and Urban Studies, Milan, Italy \\ ${ }^{3}$ Università di Messina, Dept. of Civil Engineering, Messina, Italy \\ ${ }^{4}$ Regione Umbria, CFD, Foligno, Italy \\ Correspondence to: D. Molinari (daniela.molinari@polimi.it)
}

Received: 19 December 2012 - Published in Nat. Hazards Earth Syst. Sci. Discuss.: Revised: 10 February 2014 - Accepted: 12 February 2014 - Published: 17 April 2014

\begin{abstract}
In recent years, awareness of a need for more effective disaster data collection, storage, and sharing of analyses has developed in many parts of the world. In line with this advance, Italian local authorities have expressed the need for enhanced methods and procedures for post-event damage assessment in order to obtain data that can serve numerous purposes: to create a reliable and consistent database on the basis of which damage models can be defined or validated; and to supply a comprehensive scenario of flooding impacts according to which priorities can be identified during the emergency and recovery phase, and the compensation due to citizens from insurers or local authorities can be established. This paper studies this context, and describes ongoing activities in the Umbria and Sicily regions of Italy intended to identifying new tools and procedures for flood damage data surveys and storage in the aftermath of floods. In the first part of the paper, the current procedures for data gathering in Italy are analysed. The analysis shows that the available knowledge does not enable the definition or validation of damage curves, as information is poor, fragmented, and inconsistent. A new procedure for data collection and storage is therefore proposed. The entire analysis was carried out at a local level for the residential and commercial sectors only. The objective of the next steps for the research in the short term will be (i) to extend the procedure to other types of damage, and (ii) to make the procedure operational with the Italian Civil Protection system. The long-term aim is to develop specific depth-damage curves for Italian contexts.
\end{abstract}

\section{Introduction}

The approach to natural risk assessment and management has undergone radical change in the past few decades, with a significant shift from a hazard-centred perspective to a much broader understanding of risk, which also comprises concepts such as exposure, vulnerability, resilience, and the coping capacity of systems, assets, and societies (Weichelsgartner and Obersteiner, 2002). This change has been mirrored by international initiatives at a European and global level, and by recent legislation, of which the European "Floods" Directive $2007 / 60 / \mathrm{EC}$ is a prime example. In order to protect people and assets from the impact and consequences of floods, the EU Floods Directive requires that flood risk management plans be based not only on various flood hazard scenarios, but also on risk assessments, which must present the potential adverse consequences of floods for "human health, the environment, cultural heritage, and economic activity". This assessment must first be provided in a preliminary form (Article 4 in EU, 2007), so as to identify the most critical areas, and then in a more robust and scientifically sound version (Article 6 in EU, 2007).

In Italy, responsibility for the latter is shared by the River Basin Authorities and the Ministry of the Environment as far as structural measures and land use planning are concerned, and by the National and Regional Civil Protection Authorities with regard to early warning systems and emergency preparedness. Those institutions are also coordinating the effort to develop a past flood events database, in line with the requirements set by the European Commission, in order to comply with the letters (b) and (c) of the second point of Article 4 (in EU, 2007), as briefly discussed in Sect. 2.1 (European Commission - DG Environment, 2013). 
Flood hazard and risk assessment should have been completed by December 2013, so that they can serve as the basis for developing the flood risk management plans that are due by December 2015. These plans should contain a blend of structural and non-structural measures. The effectiveness and sustainability of mitigation measures should also be evaluated through a cost-benefit analysis (Article 7.3 in EU, 2007). This requirement introduces de facto the need to estimate the potential damage to be reduced through a variety of mitigation measures. This means that even though not explicitly mentioned in the EU Floods Directive, the terms "damage" and "associated costs" must be clarified in order for the directive to be implemented correctly. To identify the most appropriate definition and the methods for qualifying and quantifying damage, public administrations often request the support of scientific expertise: this is the starting point of this article, which is the result of a collaboration between university researchers and officials from public administrations.

The scientific community itself (see Margottini et al., 2011 for a full review) has not yet reached consensus on (a) the exact definition of damage and loss, which are on some occasions treated as synonymous, and on others as conceptually different, (b) the different types of damage to which attention must be paid, and (c) the methods for assessing damage before and after a severe event. This article will address questions (b) and (c) defining damages according to what is usually done in common practice. Indeed, as for the types of damage that need to be considered, the most recent literature is in agreement on the distinction between direct and indirect damage, which may be either tangible or intangible depending on the possibility of quantifying and monetising what has been lost (FLOODSite, 2007; Meyer et al., 2013).

Direct damage generally refers to victims (the dead and injured), on the one hand, and to the physical destruction of assets, infrastructure, and individual objects on the other. With regard to the latter, the most widely used tool for estimating damage before an event are damage functions relating a hazard parameter (generally flood depth) to a given class of exposed elements characterised by certain vulnerability factors (Merz et al., 2010). These classes differ as to the uses of various zones and types of building (industrial, residential, or commercial), and/or with regard to features such as the number of floors, materials, and the existence and use of basements. A number of problems have been highlighted regarding the use of damage functions: these include the limited transferability of curves designed for one geographic area to another (see Cammerer et al., 2013), the parameters used to characterise the hazard (Merz et al., 2004; Kelman and Spence, 2004), and the criteria used to value exposed land use and/or objects. Last but not least, there is general agreement that the methods for developing and using damage functions are only relatively stable and consistent for residential areas and buildings, while in the case of other assets, such as industrial or commercial facilities and critical infrastructures, the methodologies are still at a developmental stage (see Merz et al., 2010, Jongman et al., 2012, and Meyer et al., 2013 for a full review).

The definition of indirect damage is less straightforward, and has obtained a lower level of consensus; the term "indirect damage" is used in this article to refer to the consequences generated by the direct physical damage, which is also referred to as "higher order damage" (Rose, 2004). This category includes the business interruption (Webb et al., 2000) that may be due to physical damage to industrial and commercial structures or their contents. Indirect effects are also consequences of business interruption to labour and markets. One important question that has not yet been answered is whether or not indirect damage is greater or less than direct damage. Some suggest that because of the difficulties in assessing them, they are in fact "hidden costs" (see Heinz III Center, 2000, p. 49), and that it is likely that the inability to estimate them satisfactorily biases damage estimates so that they basically include only direct physical damage (Handmer, 2002). Indirect damage is also strongly dependent on the territorial unit of measurement: national, regional, or local (Handmer et al., 2005; Hallegatte and Przyluski, 2010). More generally, it is very important to make the perspective of the evaluator explicit when counting or discounting a given impact as damage (Pielke, 2000; Handmer, 2002); gains and losses are never evenly distributed in disasters. Here, the perspective of the public administration providing preparedness for and responses to flood events, repairing infrastructures and public services, and compensating victims whenever possible, is considered. In this case, gaining a complete picture of the events (Pielke, 2000) that may occur or have just occurred is important for correctly directing funds for mitigation (both before and after the occurrence of an extreme event).

A further criticality is linked to the relevance of scale factors when conducting damage assessment or reporting. Temporal and spatial scales play a significant role in both direct and indirect damage (Downton and Pielke, 2005; Downton et al., 2005); it is clear that immediately after the impact, lost days of work and increased traffic due to the partial or total closure of infrastructures are impossible to assess; one would need to re-appraise the situation weeks and months after the event in order to be able to detect this type of impact. Time may be also relevant as far as direct physical damage is concerned, because it may only appear after some time has passed as a result of humidity or contamination. Underestimations of direct damage surveyed immediately after an event may have significant repercussions for the real level of expenditure (Comerio, 1996). With respect to the spatial scale, it may be relevant to consider the assessment of the population at risk. This is generally done by overlaying the potential hazard zones with the population living in the area; however, a much larger community may be affected, depending on the severity of the flood and its consequences for vital assets and critical infrastructures. On the other hand, the estimation of physical damage differs at a catchment or local 
scale. This is particularly the case when the most widely used tool for assessing flood risk in terms of expected direct physical damage - damage functions - is considered. The use of functions developed at a regional or large scale to assess damage in a specific locality has proved to lead to questionable results (see e.g. Cammerer et al., 2013). Section 2 of this paper briefly discusses a test conducted in the two regions of Sicily and Umbria to compare the results of the application of the flood damage functions available in the literature to the actual damage that occurred in recent events. The results were extremely disappointing, as they had been in previous attempts carried out by other researchers to develop damage functions specific to Italy in given areas (Luino et al., 2006; Freni et al., 2010). These poor results derive from a general lack of data of an acceptable quality, and they highlighted the need to make significant improvements to postflood event damage surveys. The inconsistencies in, and poor performance levels of, disaster damage databases on different scales (ranging from global to local) are the subject of a recent debate, which is also ongoing internationally (De Groeve et al., 2013). This paper contributes to this debate by briefly describing the damage data situation in Italy (Sect. 2), which justifies the effort described in Sect. 3 to develop and then test - first in exercises and then in a real event (Sect. 4) - a new method and procedure for surveying damage to a variety of objects and assets, including the development of an ad hoc survey form for residential buildings and industries. These could not, however, be developed merely for the sake of obtaining better data; they also needed to support decision-makers in prioritising and implementing recovery interventions. The process of developing a new, improved procedure for post-flood damage survey therefore serves a threefold purpose: to support recovery and reconstruction decisions, to guarantee rapid, transparent victim compensation, and to provide better data for future risk assessments.

\section{Testing available damage curves in Italy}

\subsection{Available flood damage data}

Unlike in the case of seismic risk, a standard procedure for flood damage data collection and storage at a national scale has not yet been established in Italy. The National Department of Civil Protection, which is responsible for victim compensation and for coordinating repair works on public assets, collects this information from the Regions, but each Region has established its own method and procedure.

In order to comply with the requirement to develop a database of significant past events according to Article 4.2, points (b) and (c) of the EU Floods Directive established by the European Commission, the rather large historical database developed by the Italian National Research Council (CNR) will be used. In 1989, the CNR set up the AVI project (Guzzetti et al., 1994), the aim of which was to collect the data and information that could be found in historical, municipal, and private archives and newspapers to develop a sort of historical catalogue of disasters caused by extreme hydrometeo-geological conditions, including floods, over the period between 1918 and 1990. The AVI database, which is available online, remains an important reference, even though it has not been updated since 2001, which poses the problem of how to update it using information from regional databases. The statement in the Huizinga (2007) report suggesting that no online data are available on flood damage in Italy is contestable, given the existence of the AVI database. What can be said, however, is that this information is not easy to use in the development or validation of damage functions: in the first place because the information is provided in narrative form, so that the most significant data for validation need to be reorganised into tables that are manageable for assessment purposes; second, because the georeferencing of the data is rather poor: the spatial unit of reference is a municipality at best, but especially in the case of very old data, even this information is missing or the administrative borders have changed; and third, because the description of the physical phenomena that provoked the reported damage is not uniform in all cases, and ranges from simple precipitation data to peak river discharges. In this case, too, however, geo-location is poor and water depth is never reported. Information on indirect damage is provided for certain events, but its quality depends on the sources that were available for a specific event.

At the regional level, information on flood damage is obtained from individual municipalities that collect such data in order to apply for reimbursement on the basis of the total extent of the damage incurred (it should be noted that in Italy no insurance policy covering natural hazards has to date been created for residential buildings (Maccaferri et al., 2012)), and as a consequence any form of compensation is a part of public expenditure). The damage data collected by municipalities are then organised and maintained by the Regional authorities, which receive compensation funds from central government and distribute them to affected communities on the basis of their own evaluation of what constitutes priorities and acceptable claims. Compensation can only be obtained if a state of emergency has been declared by the National Civil Protection Department. One problem deriving from the division of responsibilities among national and regional authorities is that survey methods and procedures differ from region to region, and sometimes even from municipality to municipality, which leads to inconsistencies among databases, and to poor levels of comparability. In addition, damage to different sectors, such as infrastructures, industries, and residential properties, are kept in separate archives and managed by different offices, which are responsible for compensation and reconstruction funds. Regional databases do not account for indirect damage, as it is not subject to compensation. 
A third limitation of the systematic use of these data for analysis purposes is that they are in paper form (i.e. the original survey forms). Few regions are provided with electronic structured databases such as the RasDa database in the Lombardy Region, which provides data going back to 1995. A distinction is made in the RasDa database between private and public facilities. Damage data relating to the latter is then split into damage to infrastructures and damage to buildings. In the case of buildings, whether private or public, damage to structures and contents is reported separately. As with most regional databases, a very generic description of the physical triggering event is reported, with no reference to any relevant hazard parameters. The resulting information is therefore poorer than that contained in the AVI database mentioned above. As a consequence, even though digitalised regional databases such as RasDa are better organised where they need to be used to develop or validate damage functions, the poor geo-location of damage, and especially the absence of hazard data, represents a significant barrier. One solution would be to look for other sources that provide better hazard data on the same events for which damage data are available. Meteorological, hydrologic and hydraulic information on floods that have occurred in the past may be obtained from public technical agencies such as civil protection departments (both National and Regional), river basin authorities, and monitoring and forecasting centres. Universities and research centres can also be further sources of hazard data. It is clear, however, that very considerable uncertainties would be attached to any such merger of hazard and damage data developed by different bodies that cannot easily be combined due to the absence (particularly in the case of damage data) of georeferencing.

To sum up, the existing large-scale databases in Italy are too poor to support a comparison between the results that would be obtained using damage functions from the literature and actual damage recorded in past events; at least one of the three main factors to be related - hazard, vulnerability, or damage - is always missing or too imprecise to develop a comparison.

At a local level, an attempt has been made by Luino et al. (2006) to develop a flood damage function for the residential sector using data obtained from 100 flooded buildings in one event in 2002 in the small Boesio catchment area in the Lombardy Region. The curve was obtained by interpolation across the plotted couples of flood depth and damage obtained from the survey. Freni et al. (2010) also interpolated depth-damage data to test the prediction accuracy of flood risk estimates by comparing uncertainty deriving from damage models and that due to hydraulic modelling. Detailed data on flooding events and consequent damage over a five-year period (1993-1997) in the historic centre of the city of Palermo, which is exposed to frequent - though minor - flooding were provided by local fire brigades. One of the conclusions of this study was that "additional damage data is more valuable than the implementation of a more detailed [hydraulic] model". The problem with interpolation techniques is the high level of uncertainty in the depth-damage curves, as shown by Freni et al. (2010), and the fact that they can be deemed reliable only for the specific context for which they were obtained, as stated by Luino et al. (2006).

\subsection{A test conducted in two Italian regions}

The authors of this paper made a further attempt to compare assessed damage obtained through the use of damage functions and real, surveyed damage in the city of Barcellona, Sicily, which is prone to flash floods, and in the Nerina Valley in Umbria, which is prone to riverine floods. These two areas were affected by severe events occurring in November 2011 and November 2005. The test relied on the fact that public officials from the two regions actively contributed, which permitted easy access to available data in all formats. The results were rather disappointing, however, mainly because of the absence or poor quality of available data. The situation is summarised in Table 1.

In the case of Barcellona, vulnerability data and a flood depth map obtained through hydraulic modelling were available for 52 out of the 577 buildings reported to have been damaged. Both data sets were of good quality: vulnerability data were obtained through direct surveys carried out by public officials and refined by researchers, while hydraulic modelling was carried out using measurements from the actual event. Economic damage data were not made available, however, due to the fact that the compensation process was still ongoing, and this type of information was considered to be too critical to be shared with researchers.

In the case of the Nerina Valley, data relative to the event, vulnerability and compensated damage were available, but for too limited a number of buildings. In fact, owing to the way in which the damage surveys had been conducted, crucial information, such as the flood depth at the exact locations where damage had been surveyed, was often missing, and the definition of parameters such as maintenance levels and building types was poor and inconsistent. Out of the 35 damage records that were available at the beginning of the test, only 22 provided the exact water depth, and out of these 22 , the building surface area was actually available for just 16. The test was carried out despite these limitations, and obviously showed a poor match with all four selected curves: the Dutch Standard Method (Kok et al., 2005), the USACE (USACE, 2003), the German FLEMOps (Thieken et al., 2008) and the curve developed by Luino et al. (2006) (see Fig. 1). While this result has no statistical meaning, it is in line with similar attempts that have been made elsewhere in Europe (e.g. Jongman et al., 2012; Cammerer et al., 2013). In detail, Fig. 1 highlights two interesting aspects. On the one hand, there is a difference between observed damage and damage estimated by each curve. This scatter is due to the fact that depth-damage curves supply an average value for the damage, even within a specific vulnerability class, so 
Table 1. Hazard (H), exposure (E), vulnerability (V) and damage (D) information, collected in the Umbria and Barcellona case study. The table shows that information on the water depth and building surface is the most critical, as its lacking reduces the sample size. Present shortcomings derive from the fact that water depth and building area are not compulsorily requested in damage forms/technicians' estimates; on the other hand, building areas cannot be derived from the land registry, as it does not cover the entire national territory.

\begin{tabular}{|c|c|c|c|c|c|c|}
\hline \multirow{2}{*}{ Variable } & \multicolumn{3}{|c|}{ UMBRIA } & \multicolumn{3}{|c|}{ Barcellona } \\
\hline & Information & Source & N. Items & Information & Source & N. Items \\
\hline $\begin{array}{l}\text { Hazard } \\
(\mathrm{H})\end{array}$ & $\begin{array}{l}\text { - Water depth at building } \\
\text { location } \\
\text { - Flooded area }\end{array}$ & $\begin{array}{l}\text { event report } \\
+ \text { technicians' } \\
\text { estimates }\end{array}$ & 22 buildings & $\begin{array}{l}\text { - Water depth at building } \\
\text { location } \\
\text { - Flooded area }\end{array}$ & field survey & 52 buildings \\
\hline $\begin{array}{l}\text { Exposure } \\
\text { (E) }\end{array}$ & - Building area & $\begin{array}{l}\text { land registry + } \\
\text { technicians' } \\
\text { estimates }\end{array}$ & 16 buildings & - & - & - \\
\hline Vulnerability (V) & $\begin{array}{l}\text { - Building use } \\
\text { - Presence of basement } \\
\text { - Number of floors } \\
\text { - Use of basement } \\
\text { - Level of maintenance }\end{array}$ & $\begin{array}{l}\text { land registry + } \\
\text { technicians' } \\
\text { estimates }\end{array}$ & 35 buildings & $\begin{array}{l}\text { - Building use } \\
\text { - Building typology }\end{array}$ & $\begin{array}{l}\text { technicians' } \\
\text { forms }\end{array}$ & 577 buildings \\
\hline $\begin{array}{l}\text { Damage } \\
\text { (D) }\end{array}$ & $\begin{array}{l}\text { - Building location } \\
\text { - Damage description } \\
\text { - Absolute economic } \\
\text { damage }\end{array}$ & $\begin{array}{l}\text { technicians' } \\
\text { estimates }\end{array}$ & 35 buildings & $\begin{array}{l}\text { - Building location } \\
\text { - Damage description } \\
\text { - Damaged floor }\end{array}$ & $\begin{array}{l}\text { technicians' } \\
\text { forms }\end{array}$ & 577 buildings \\
\hline
\end{tabular}

that singularity (i.e. the damage for a specific building of a class) is hardly predicted. It is plausible that, if more than few data are available for each vulnerability class, the average observed data for each class would better fit with curve estimates. On the other hand, Fig. 1 highlights the fact that different curves supply different estimates for the same damage, as to say that uncertainty in damage curve estimation is high (see Handmer, 2002; Merz et al., 2004; Jongman et al., 2012). Test results also stress the limitations due to the available data sets, as demonstrated elsewhere even where insurance records are used (see André et al., 2013).

However, despite the rather disappointing result, the test permitted us to point out certain fundamental weaknesses and problems associated with the way damage functions are currently developed and applied. The first is the difficulties involved in transferring curves from one site to another without prior checks being carried out. This has also been demonstrated by attempts to use functions developed in Germany for Austrian cases (Cammerer et al., 2013). The second relates to the spatial scales mentioned in the introduction: while many of the damage functions based on real data from past floods were obtained from large data sets collected during very large events, the data that can be obtained in Italy are generally of a much smaller size, and relate to generally much smaller catchment areas, even though the events may be frequent. Furthermore, these events are scattered across a wide spectrum between riverine and mountain floods, for which, as suggested by Merz et al. (2004), water depth is not sufficient to explain consequential damage. Variations in

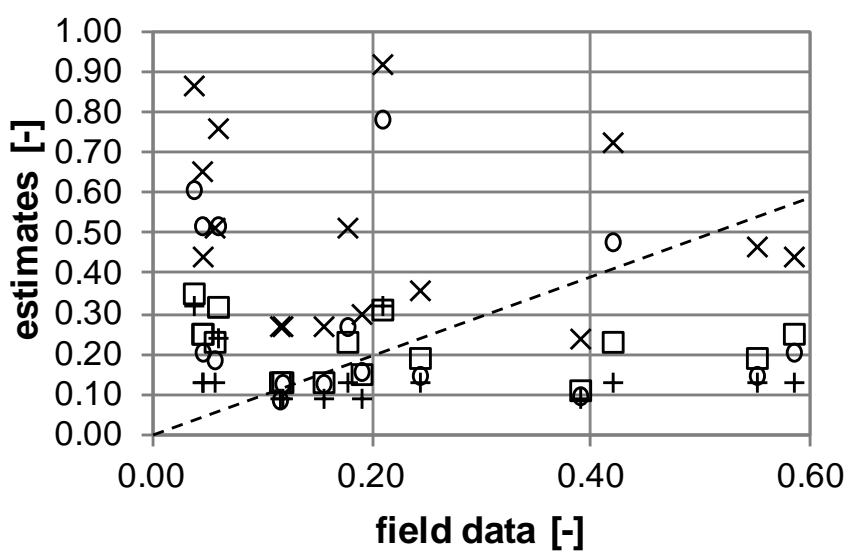

$\times$ USACE

+FLEMO_ps

\section{o Standard Method}

口Luino etal.

Fig. 1. Comparison among relative observed damage data for the Umbria case study (i.e. field data) and estimates supplied by existing depth-damage curves.

the geographical and geomorphological contexts as well as those of territories characterised by the differing urban patterns and building typologies that are typical of Italy make it difficult either to generalise damage functions or to obtain large enough data sets to achieve statistical relevance. 
Certainly, however, much can be done to improve the quality of data for all parameters that are needed: that is, georeferenced hazard, vulnerability, and damage indicators based on univocal criteria that will allow greater and more consistent comparability in the future. A similar path was taken almost 40 years ago (after the Friuli disaster in 1976) in the seismic field in Italy: thousands of records are now available to provide for reliable damage - or as they are known in the seismic domain - vulnerability functions. The public administration officials who participated in our test recognised the need to develop procedures and tools for improved quality data collection following floods. The procedures and survey forms that will be described in the next section were developed and tested with these officials in both exercises and a real event.

\section{Procedure for field data collection}

The previous section clearly showed the weaknesses of postflood data collection procedures in Italy. In order to develop a new method and procedures, the tools available in the literature and from past experiences have been researched and analysed.

There are not many comprehensive post-event damage assessment tools, and most of them are quite new. Among them are the PDNA (Post Disaster Needs Assessment) methodology resulting from the collaboration of a number of institutions, including the EU Commission, UN, the World Bank and others (for an application see Wergerdt and Mark, 2010), which is a very important example, and the one from which we took inspiration for our own efforts. In particular, the PDNA is interesting in that it attempts to provide a "complete picture" of a disaster, identifying damage to various sectors of the economy and society. The PDNA requires that first a damage and loss assessment is carried out (DALA) for several sectors that are important in the economy and services of the stricken area. Such assessment is carried out towards a number (generally four) steps that serve first to define a preliminary post-event damage scenario, then to proceed from a fast preliminary joint multi-sectoral rapid assessment, towards a much more in depth one. It is a procedure thought for developing countries, with a strong emphasis on international and donors interventions: this has to be kept in mind while adapting its core concepts to a developed context. What has been kept of the PDNA methodology in our own effort is on the one hand to construct a progressively more detailed and in depth assessment using the same indicators and on the other to identify different sectors for which an assessment is relevant (economic, services, residential sectors).

The WMO (2007) has issued its own recommendations for post-flood event damage assessment, including several steps and issues that we have also considered. In particular, the WMO recommends re-running surveys a minimum number of times in order to identify damage that occurs or becomes manifest within a certain period after the end of the physical event. As for attempts at a national level, we would cite the French case, which is particularly relevant as regards surveying damage to business (Ministère de l'aménagement du territoire et de l'environnement, 2000) and the Australian case, as described by King (2002).

The procedure that has been, and remains, in development requires two sets of activities. The aim of the first is to gather data independently from a variety of agencies and subjects in a coordinated manner. In the Umbria case, the Regional Civil Protection Department took responsibility for producing a complete post-flood event scenario report jointly with us, providing the "integrated interpretation" of the event that Pielke (2000) considers to be essential. The second set of activities consists of direct surveys in the field to estimate damage to a variety of systems and assets, using newly developed survey forms (see tables 2 and 3 ). In this section, only the part of the procedure which consists of developing and applying survey forms for residential buildings and businesses is illustrated (see Table 4).

In order to develop this second part of the new procedure, four main steps had to be carried out:

- development of the forms for collecting data in field surveys after the flood;

- explaining how to use the forms in the field and the professional requirements for surveyors;

- development of an instruction kit for training surveyors;

- explaining how to input the collected data into a computerised version so as to be able to store them and use them in subsequent analyses and interpretations.

A first draft of the survey form was tested in mid-June and early October 2012 with public officials at regional and provincial level in Umbria and Sicily respectively, in two ad hoc exercises. These tests enabled us to identify certain criticalities that needed to be corrected. In particular, the public officials suggested that we make the new forms similar to those that had been well tested and widely used for assessing the usability of buildings after seismic events (see Baggio et al., 2007). As Umbria had experienced a severe seismic event in 1997, everybody was familiar with these forms, and expected to find a similar structure in those to be developed for floods. This requirement was implemented in the subsequent version of the form, obviously while taking into consideration the differences in the type of physical stress due to flooding (both flash and plain floods) compared with shaking ground.

The test proved essential when the flood of 12 November 2012 required use of the damage survey procedures in real-life circumstances. The November flood provided an important opportunity to fully test the validity of both the proposed procedure and the associated data collection forms, 
Table 2. Sections and relative aspects to be evaluated in the form.

\begin{tabular}{|c|c|c|}
\hline Section & Description & Aspects \\
\hline \multicolumn{3}{|l|}{ Form A: General information } \\
\hline 1. General information & $\begin{array}{l}\text { Includes aspects } \\
\text { - to identify building locations. } \\
\text { - describing under what conditions the survey was } \\
\text { carried out. }\end{array}$ & $\begin{array}{l}\text { - geographic coordinates } \\
\text { - land registry coordinates } \\
\text { - address } \\
\text { - who carried out the survey } \\
\text { - with/without support }\end{array}$ \\
\hline 2. Building features & $\begin{array}{l}\text { Includes aspects to characterise building expo- } \\
\text { sure/vulnerability. }\end{array}$ & $\begin{array}{l}\text { - building typology (i.e. detached house, apartment } \\
\text { building/semi-detached house, public building) } \\
\text { - period of construction } \\
\text { - building structure (e.g. concrete, masonry, wood, } \\
\text { steel) } \\
\text { - surface } \\
\text { - number of floors } \\
\text { - building elevation }\end{array}$ \\
\hline 3. Description of flood event & $\begin{array}{l}\text { Includes aspects that are important for character- } \\
\text { izing stress on the building. }\end{array}$ & $\begin{array}{l}\text { - duration } \\
\text { - water depth outside the building } \\
\text { - presence of sediments/contaminants }\end{array}$ \\
\hline 4. Description of the damage & $\begin{array}{l}\text { Includes aspects that are important for identify- } \\
\text { ing affected parts of the buildings and forms to be } \\
\text { compiled. }\end{array}$ & $\begin{array}{l}\text { - affected parts (i.e. number of housing units, com- } \\
\text { mon areas, number of attached buildings, structural } \\
\text { damage) } \\
\text { - forms to be compiled (i.e. A, B, C, D, E) }\end{array}$ \\
\hline
\end{tabular}

FORM B: Damage to housing unit. NB This form must be filled in for every unit in the building.

\begin{tabular}{|c|c|c|}
\hline 5. General information & $\begin{array}{l}\text { Includes aspects } \\
\text { - for identifying the property. } \\
\text { - for describing affected floors. }\end{array}$ & $\begin{array}{l}\text { - owner } \\
\text { - damaged floors }\end{array}$ \\
\hline $\begin{array}{l}\text { 6. Damage to affected floor X } \\
\text { NB This section needs to be filled in for ev- } \\
\text { ery affected floor in the unit. }\end{array}$ & $\begin{array}{l}\text { Includes: } \\
\text { - further aspects that are required to fully char- } \\
\text { acterise the exposure/vulnerability/location of the } \\
\text { floor as well as the stress on it } \\
\text { - all aspects that are required to characterise the } \\
\text { direct damage to the floor } \\
\text { - certain aspects relating to indirect damage } \\
\text { - certain aspects relating to mitigation actions }\end{array}$ & $\begin{array}{l}\text { - surface } \\
\text { - level of maintenance } \\
\text { - technological systems } \\
\text { - use (e.g. residential, commercial, storage, etc.) } \\
\text { - maximum water depth inside the building } \\
\text { - damage to: coating/plaster, windows and doors, } \\
\text { floor, technological systems, contents } \\
\text { - loss of usability } \\
\text { - clean-up cost } \\
\text { - mitigation actions: type of action, time of action, } \\
\text { motivation }\end{array}$ \\
\hline
\end{tabular}

FORM C: Damage to common areas

\begin{tabular}{lll}
\hline 7. General information & $\begin{array}{l}\text { Includes aspects } \\
- \text { for describing affected floors. }\end{array}$ & - damaged floors \\
\hline $\begin{array}{l}\text { 8. Damage to affected floor X } \\
\text { NB This section needs to be filled in for ev- } \\
\text { ery affected floor in the common areas }\end{array}$ & $\begin{array}{ll}\text { Includes the same aspects as form B, section } 2 . \\
\text { FORM D: Damage to attached building. NB This form must be filled in for every attached building. }\end{array}$ \\
\hline $\begin{array}{l}\text { 9. General information } \\
\text { Includes aspects } \\
- \text { for identifying the building locations. } \\
- \text { for identifying the property. }\end{array}$ & $\begin{array}{l}\text { - geographical coordinates } \\
\text { - owner }\end{array}$
\end{tabular}


Table 2. Continued.

\begin{tabular}{|c|c|c|}
\hline Section & Description & Aspects \\
\hline 10. Building features & $\begin{array}{l}\text { Includes aspects for characterising building expo- } \\
\text { sure/vulnerability. }\end{array}$ & $\begin{array}{l}\text { - period of construction } \\
\text { - building structure (e.g. concrete, masonry, wood, } \\
\text { steel) } \\
\text { - surface } \\
\text { - number of floors } \\
\text { - building elevation }\end{array}$ \\
\hline 11. Description of flood event & $\begin{array}{l}\text { Includes aspects that are important for character- } \\
\text { ising stress on the building. }\end{array}$ & $\begin{array}{l}\text { - duration } \\
\text { - water depth outside the building } \\
\text { - presence of sediments/contaminants }\end{array}$ \\
\hline 12. Description of the damage & $\begin{array}{l}\text { Includes aspects that are important for identifying } \\
\text { damaged floors. }\end{array}$ & - Affected floors \\
\hline $\begin{array}{l}\text { 13. Damage to affected floor X } \\
\text { NB This section needs to be filled in for ev- } \\
\text { ery affected floor in the building. }\end{array}$ & Includes the same aspects as form B, section 2 . & \\
\hline \multicolumn{3}{|l|}{ FORM E: Structural damage } \\
\hline 14. Structural damage & $\begin{array}{l}\text { Includes aspects for fully characterising structural } \\
\text { damage to the building. }\end{array}$ & $\begin{array}{l}\text { - Affected elements: identification and extension (i.e. } \\
\text { damaged elements as a percentage of the total) } \\
\text { - Causes of collapse }\end{array}$ \\
\hline
\end{tabular}

and to improve and adapt them further to the needs of the local context.

\subsection{Description of the field survey form for residential buildings and industrial facilities}

The newly developed forms required the collection of data that would be relevant to the need to overcome the problems that had been encountered during the trial illustrated in Sect. 2, in particular:

- the required hazard, exposure, and vulnerability factors are addressed;

- clear and univocal criteria are provided for assessing the indicators that may lead to subjective judgments, such as the level of maintenance;

- partial coverage of information on damage: this is the most crucial item of information for an empirical estimate of damage models, and should always be collected after a flood event.

- The survey forms layout (see Table 3) has been designed so as to recall the one used to assess the usability of buildings after earthquakes.

The form for residential buildings responds to certain basic requirements, as follows:

- the form has been conceived to be flexible and easy to use in different situations, which may derive from the specific features of the houses to be surveyed, which may be multi-floor condominiums, small detached houses, medium-size buildings with only a few floors and a limited number of dwellings in them, large blocks of individual buildings each containing one or more dwellings, etc. In order to cover the largest possible number of different situations, the forms are organised into coloured sheets corresponding to the building as a whole, the common areas (entrance, stairs), and individual dwellings. They may be completely or only partly filled in, depending on the specific characteristics of the building to be surveyed.

- The forms were therefore designed to collect data at both levels, in order to serve both modelling and compensation purposes. In fact, while damage models usually supply and consider damage at a whole building level, compensation is made for each housing unit (including those in the same building).

- For each unit to be assessed, the basic architectural features are reported: namely, size, height, number of floors, existence of basement and attached areas, etc. (see Table 2).

- For each unit, certain information is collected on the flood, in particular the flood depth, ensuring that a certain known level reference is taken into account and that the depth is reported for both inside and outside walls, the duration of the flood, and the presence of contaminants and /or sediments (see Table 2).

- For each unit, the damage is reported, distinguishing between damage to structural and non-structural 
Table 3. Extract from the forms.

SECTION 2: Building features

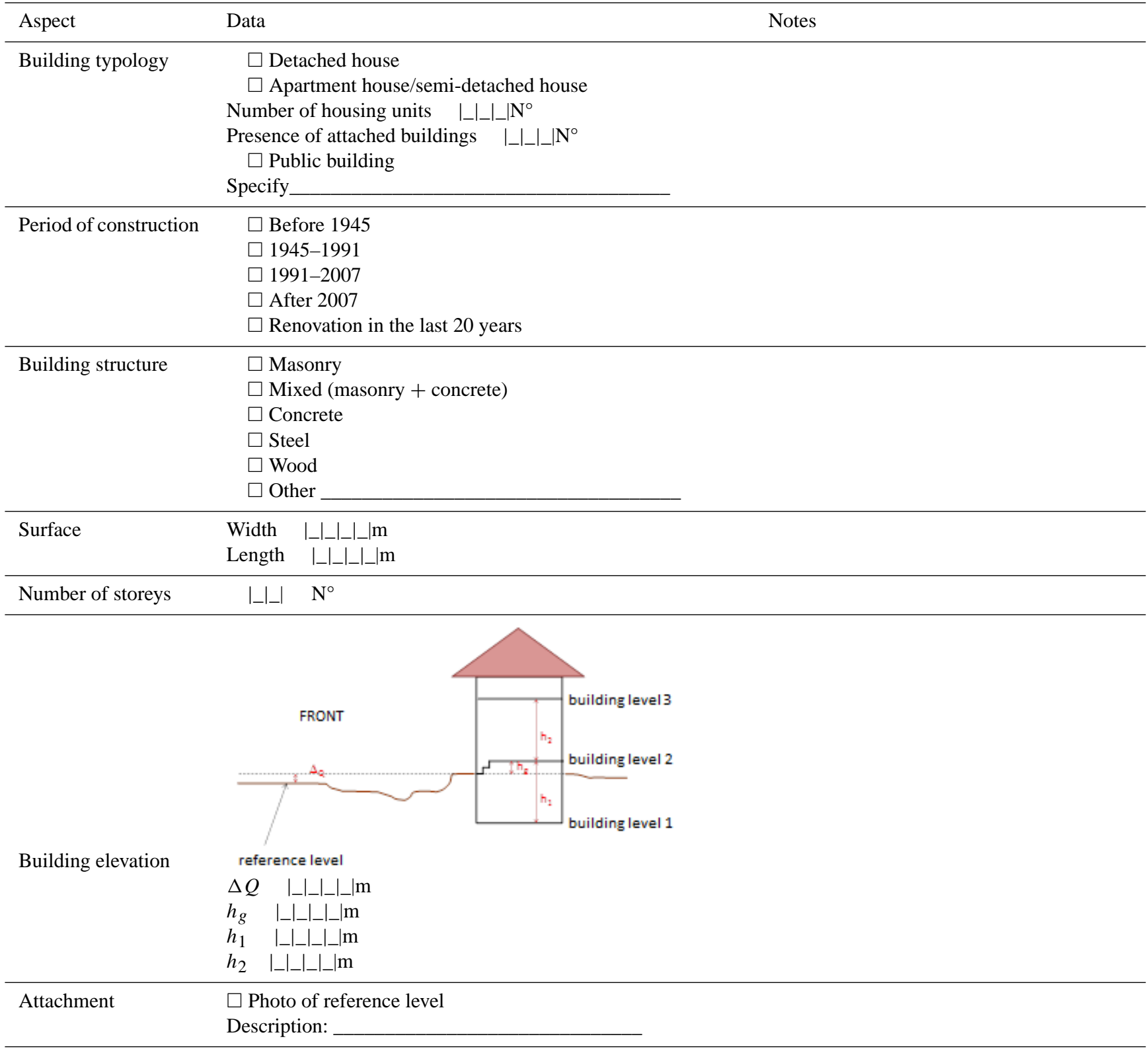

components, such as windows, doors, and walls and contents, including technical equipment (see Table 2).

- For each unit, certain information regarding mitigation actions taken during the warning period and prior to the event.

- As for indirect damage, the number of days spent in evacuation shelters or with relatives and friends, and the time and cost needed for clean-up are reported (see Table 2).
The forms involve the collection of two kinds of data:

- "objective" data such as water depth, number of floors, etc.; and

- "subjective" data such as levels of maintenance, economic damage, etc., the valuation of which may change according to the subjective view of the collector or the estimation method adopted.

In order to avoid inconsistencies due to subjective judgements as much as possible, criteria are provided that adopt 
Italian legislation or practice wherever possible: for example, the "level of maintenance" (see Table 5) is classified as much as possible according to the definition adopted by the Real Estate and Property Price Database.

The form for industrial facilities is very similar as far as organisation and layout are concerned, although a much more detailed description of damage to interior machinery and its condition (whether or not it was in working order at the time of the event), equipment, raw materials and finished products, and the quantity and quality of stock is provided.

In addition, the section regarding indirect damage is more developed, and includes questions relating to lost working days, lost clients, and the consequences for labour. The indicators that are specifically relevant for industries have also been drawn from previous reports available on floods affecting industrial areas in France (see Ledoux, 2000).

\subsection{First "emergency" application after the flood that struck the Umbria Region in November 2012}

The event that struck Umbria in November 2012, which began on the 12th and ended on the 16th, depending on the exact location and river basin, was the consequence of a widespread, high-intensity storm. The storm caused floods and landslides over large areas of Central Italy, including, besides Umbria, the Lazio and Tuscany regions. The total of first-order costs to cover emergency response, the recovery of infrastructures and a first response to restart economic activities and public services (such as schools) in the stricken regions was EUR 250000000 . Activities to develop a comprehensive damage report are still ongoing, and have been included in the field survey. Data collection from organisations and agencies was carried out jointly by the Regional Civil Protection Departments and the team from the Politecnico di Milano.

In Table 6 detailed data regarding the surveys conducted in the field are shown. The timing, personnel effort, extent of surveyed objects are listed. Thanks to the direct involvement of regional officers, no particular obstacle was encountered in the direct surveys: victims proved to be extremely collaborative and even willing to share their experience and concerns with us. This positive reaction can be partially explained by the wish to get some compensation for the damage, even though during the visits it was made clear that this was not the purpose of our survey. The average time needed for each building ranged between thirty minutes and one hour, depending on the number of individual dwellings to be checked and the desire of the people being interviewed to talk to the surveyors. Even though this may seem a waste of time in terms of survey efficiency, it was not, for a number of reasons. First, it is important for the public administration to show that regional and local governments care about the victims, and that activities are continuing even months after the disaster. Second, people sometimes provide important information relative to the circumstances of the event, to its early signs, or to previous, though minor, floods in the same area. If carefully considered, this information is very significant for the design of future mitigation actions and for establishing a relationship of trust between citizens and the regional and local authorities, which will be important for the implementation of mitigation plans and measures. Third, it is worth noting that the time that proved necessary to survey each building was consistent with similar experiences after earthquakes using the usability assessment forms referred to above.

Nevertheless, the overall time needed for surveys and back office work to input the data remains a major concern, particularly if such events become more frequent in the future. One of the reasons why the procedure proved to be long to implement may be ascribed to the insufficient standardisation achieved by the time the real emergency occurred. The emergency testing, whilst very useful, added challenges that could not be easily met by a procedure that was still under development.

Despite those pitfalls, the mixed researcher/regional teams proved to be able to adjust rather well to the evolving situation in the field. The three rounds of surveys in the flooded areas became part of an adaptive process, where the regional government officials and the researchers from the Politecnico di Milano increased the efficiency level of the entire process. On the second, and particularly the third visit, many more people were involved than in the first one, more teams could be formed, and a much larger area was covered. In between these rounds, the forms were reviewed and made easier to compile. During the last two visits, more time was devoted to the initial training of surveyors to make them comfortable with both the forms and the procedure. In addition, the accompanying material, such as satellite and aerial maps of the areas to be covered, was improved, which speeded up the back office work needed to input the data into the GIS.

\subsection{Initial results of application of the procedure after the November flood in Umbria}

Surveyed data were collected into a database, analysed and interpreted; finally maps were produced as well as other relevant results representations. These are, obviously, a part of the comprehensive post-flood scenario report that is the final aim of the entire procedure, but only the preliminary results of the post-processing can be shown here.

With regard to the flood event, the information gathered during the survey enabled us to produce a first draft of a map of the flooded areas, since satellite images were not made available, while more detailed and accurate maps were still under development during the first months. Examples of the maps obtained from the surveyed data can be seen in Figs. 2 and 3 relative to the area of Ponticelli (in the Municipality of Città della Pieve) and Orvieto. Interesting information was also obtained regarding the duration of the flood: while in the former the high water lasted for at least a couple of days 
Table 4. Procedure for data collection and storage in the aftermath of flood events.

\begin{tabular}{|c|c|}
\hline Step & Action \\
\hline $\begin{array}{l}\text { Before the event (i.e. time } \\
\text { of peace) }\end{array}$ & $\begin{array}{l}\text { - Pre-compiled forms for all buildings within flood hazard zones } \\
\text { - Definition of collector teams }\end{array}$ \\
\hline $\begin{array}{l}\text { Aftermath of the event: } \\
\text { step } 1\end{array}$ & $\begin{array}{l}\text { - Identification of damaged buildings to be surveyed on the basis of flooded areas } \\
\text { - Collector team assignment }\end{array}$ \\
\hline $\begin{array}{l}\text { Aftermath of the event: } \\
\text { step } 2\end{array}$ & - Field surveys and forms compilation \\
\hline $\begin{array}{l}\text { Aftermath of the event: } \\
\text { step } 3\end{array}$ & $\begin{array}{l}\text { - Validation of collected data } \\
\text { - Storage of collected data } \\
\text { - Planning of a detailed survey if required (e.g. to better collect data that it is not possible to validate) }\end{array}$ \\
\hline $\begin{array}{l}\text { Aftermath of the event: } \\
\text { step } 4\end{array}$ & - Detailed survey, if required \\
\hline $\begin{array}{l}\text { After emergency: } \\
\text { step } 1\end{array}$ & $\begin{array}{l}\text { - Final validation of collected data } \\
\text { - Storage of collected data }\end{array}$ \\
\hline $\begin{array}{l}\text { After emergency: } \\
\text { step } 2\end{array}$ & $\begin{array}{l}\text { - Reproduction of hazard scenario (e.g. peak water discharge, flooded areas, water depth, water veloc- } \\
\text { ity, etc.) on the basis of collected data }\end{array}$ \\
\hline Aspects & Guidelines \\
\hline Level of maintenance & $\begin{array}{l}\text { The level of maintenance is "bad" if, before the flood, } \\
\text { - floors were missing or severely damaged (more than } 20 \% \text { of total surface area); } \\
\text { - coverings/plaster was missing or severely damaged (more than } 10 \% \text { of total surface area); } \\
\text { - walls were severely damaged; } \\
\text { - more than one external opening was missing or in bad condition; } \\
\text { - the electrical and plumbing systems were not designed/built according to the law. } \\
\text { When openings, floors, coverings/plaster and roof were new/preciousness and systems were function- } \\
\text { ing, the level of maintenance is "good". } \\
\text { Otherwise, the level of maintenance is "normal". }\end{array}$ \\
\hline
\end{tabular}

(some mentioned from the 12 to the 16 November 2012 in the lower-level zones), in Orvieto the flood was very rapid, and lasted just a few hours (people were able to return to their businesses by the early afternoon of 12 November 2012).

Gathered information regard also the vulnerability of affected buildings. Figure 4 shows for example the typology of surveyed buildings in terms of single houses, detached/apartment houses, attached buildings or public buildings.

The most frequently reported physical damage to residential dwellings was damage to windows and doors, damage to walls and floors, and complete flooding of basements, where present, with the loss of most of their contents. Damage to contents was generally heavy: to electrical equipment and appliances of all kinds, and to personal belongings such as clothing, photos, and furniture. Fine sediments, and sometimes oil, moved by the flooding water further aggravated the damage (for details see Figs. 5 and 6 for Città della Pieve).

Direct damage to industrial facilities and businesses was certainly heavier, as both interior machinery and raw materials and finished products were involved. Businesses also lost computers, documents, and business cars and vans. 94 cars were heavily damaged at one car dealer and garage in Orvieto. Had the retailer received an early warning, he might perhaps have saved at least some of the cars by taking them to the large parking area on the top floor, which the water did not reach.

With regard to the mitigation actions that were taken, differences may be found in the three municipalities surveyed: in Città della Pieve, and particularly in Marsciano, people were alerted house-by-house by civil protection volunteers, who were complying with the regional alarm that had been issued on Saturday, 10 November (two days before the 
Table 6. History of field surveys.

\begin{tabular}{llll}
\hline Period & Number of teams and composition & Surveyed towns & Surveyed building \\
\hline $\begin{array}{l}\text { Early December (ten days after the } \\
\text { flood) }\end{array}$ & $\begin{array}{l}5 \text { teams of two people (researcher, civil } \\
\text { protection personnel) }\end{array}$ & $\begin{array}{l}\text { Marsciano } \\
\text { Città della Pieve }\end{array}$ & $\begin{array}{l}16 \text { residential } \\
2 \text { industrial }\end{array}$ \\
\hline $\begin{array}{l}\text { Late January } \\
\text { (two months after the flood) }\end{array}$ & $\begin{array}{l}6 \text { teams of two people (researcher, civil } \\
\text { protection personnel) }\end{array}$ & $\begin{array}{l}\text { Città della Pieve } \\
\text { Orvieto }\end{array}$ & $\begin{array}{l}32 \text { residential } \\
6 \text { industrial }\end{array}$ \\
\hline $\begin{array}{l}\text { Middle March (four months after the } \\
\text { event) }\end{array}$ & $\begin{array}{l}11 \text { teams of two people (researcher, civil } \\
\text { protection personnel, trained/qualified } \\
\text { volunteers: architects, engineers, geolo- } \\
\text { gists) }\end{array}$ & & 128 residential \\
& & & \\
\hline
\end{tabular}

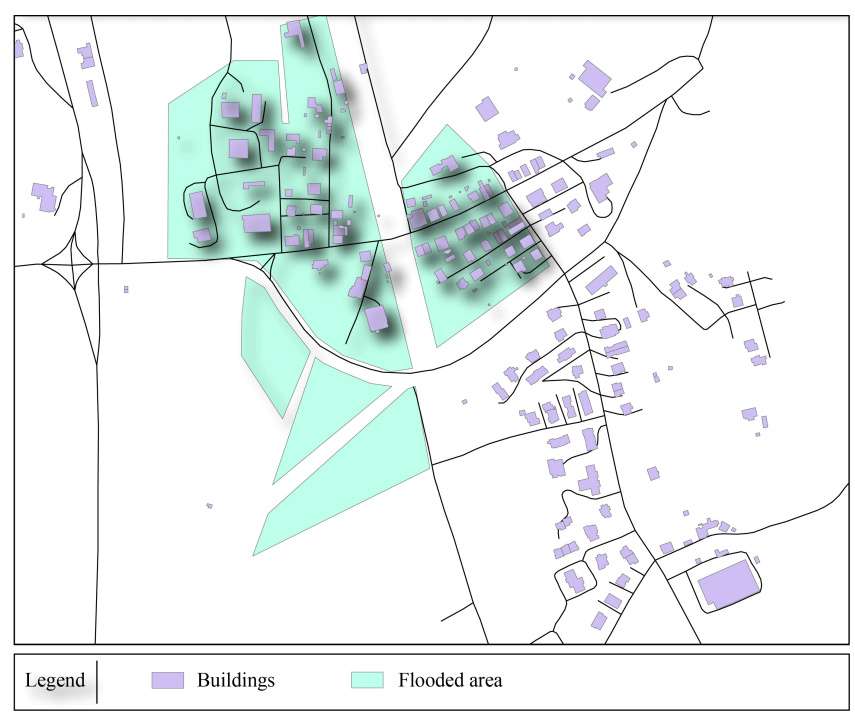

Fig. 2. Flood zone in the Ponticelli area, Città della Pieve.

flood). In Orvieto, on the other hand, an early warning was not given to residents and business owners, who were prevented from reaching their places of work very early in the morning when the civil protection officials closed the bridge connecting the more residential part of the town and the industrial zone, as the risk level had been reached at around 5:30 a.m. in the morning.

With regard to longer-term mitigation, it must be recalled that insurance coverage against natural calamities is not available for private households in Italy, while the business owners that we interviewed said they could not afford it as the premium are too high (and perhaps they had not perceived themselves at risk before last year's flood).

As for indirect damage, the residents complained about the time needed for clean-up, which was an activity that required a good deal of effort due to the sediments and contaminants. Nevertheless, residents and business owners were helped by volunteers and neighbours, and did not have to pay for the clean-up. The municipalities took care of the toxic waste, particularly in the industrial zone of Orvieto. Some families in Città della Pieve had to stay in hotels or with relatives for some days while they waited for the water to recede and for basic services like water and electricity to be restored.

The indirect damage was certainly heavier for businesses, not only because they could not recommence activities (at the time of our first survey, ten days after the flood, most activities were still blocked or had only just restarted at a much reduced pace), but also because there was no certainty regarding how to handle incoming orders. During the third visit, the surveyed businesses reported that they went back to full activity between the months of January and November 2013. As a consequence, some had to ask for unemployment benefits to be paid to workers who remained jobless for a certain period.

\section{Conclusions}

The work described in this paper has one very important feature that must be mentioned: the methods and procedures were not developed for decision-makers, but with them. Stakeholder involvement in projects has been an increasing requirement of many project calls launched by the European Commission for FP7, but there is a significant difference between interviewing stakeholders to obtain feedback on work that has already been carried out in research centres and developing tools and methods jointly. This type of activity can be labelled as "participatory research", intended as adopting a set of techniques that "are interactive and collaborative, providing a meaningful research experience that both promotes learning and generates research data through a process of "guided discovery" (Mercer et al., 2008). In fact, the type of collaborative work that has been carried out with public administrations of the Sicily and, more thoroughly, Umbria regions has a number of characteristics associated with "participatory research". Following the analysis carried out by Cornwall and Jewkes (1995), this experience was clearly aimed at producing "knowledge for action", adapted scientific methodologies to new contexts, and has been drawn from research questions that were formulated by multiple stakeholders. However, our experience differs from 


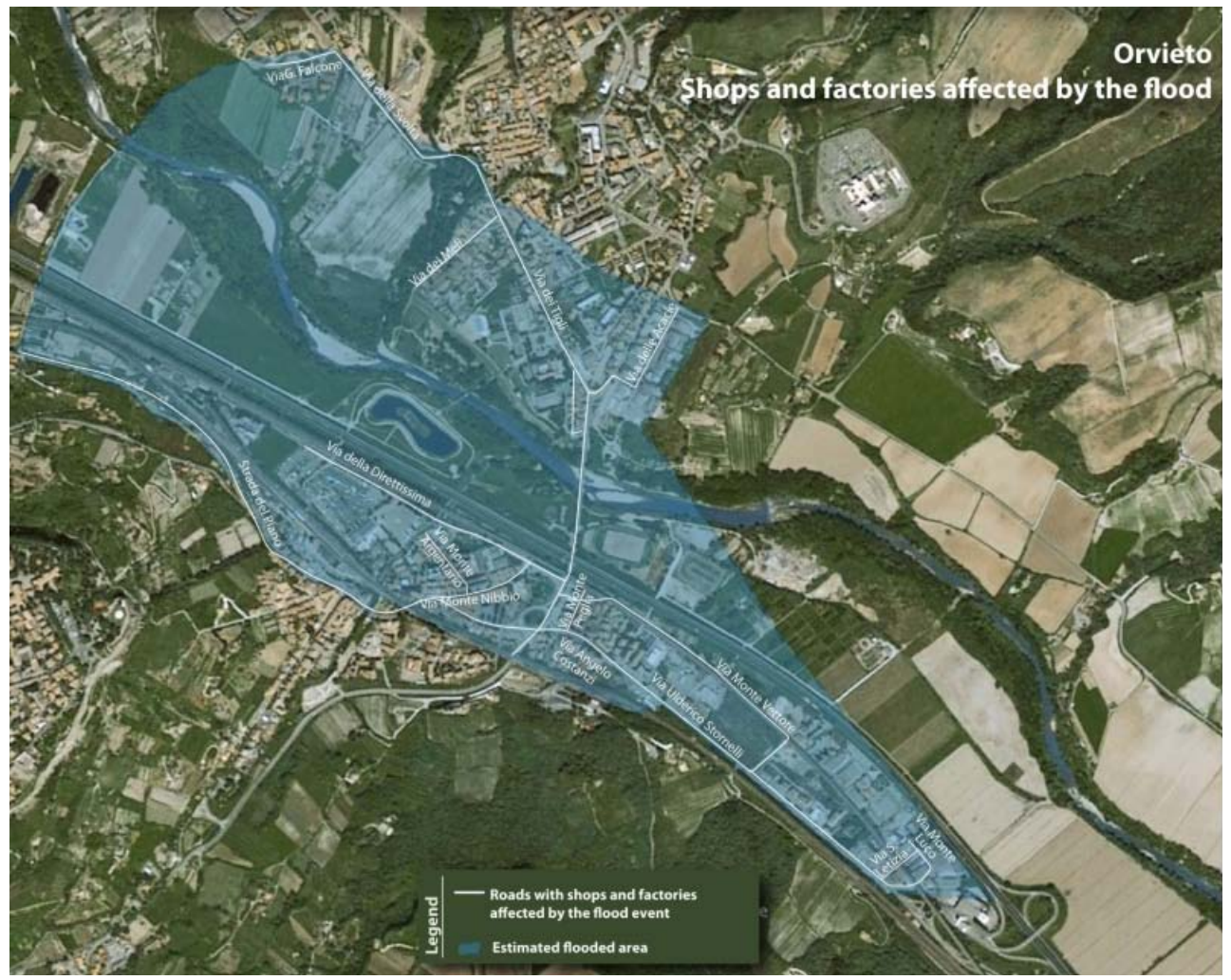

Fig. 3. Flood zone in Orvieto.

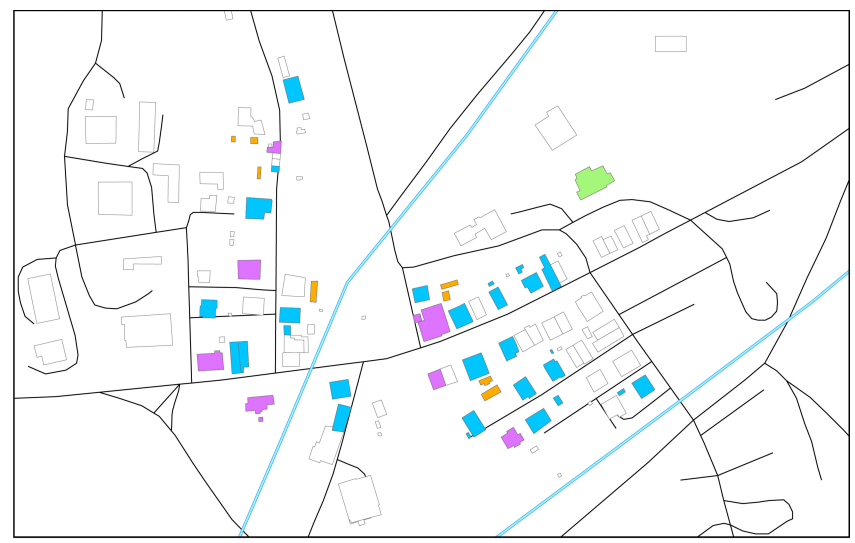

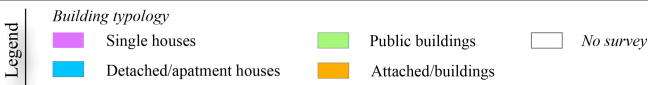

Fig. 4. Surveyed buildings in Città della Pieve by building type.

the widely understood form of participatory research in that it was not designed by researchers to get data and insight in a different way; rather, it was the result of an integrative form of collaboration well established between researchers and officials of the public sector. In this respect, the term "pracademic" as intended by Posner (2009) is perhaps more appropriate. In fact, this experience has been possible thanks

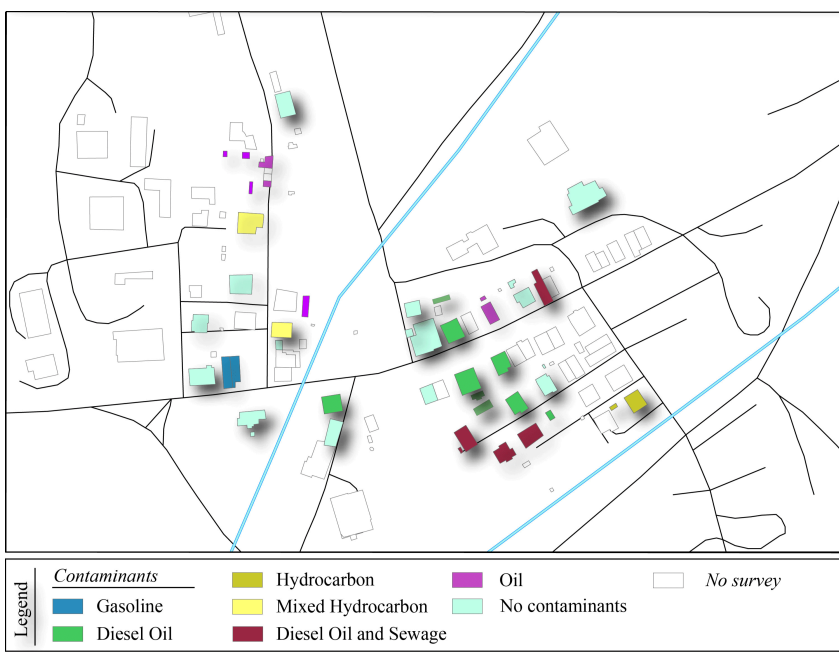

Fig. 5. Contaminants in the surveyed buildings in Città della Pieve.

to a rather different mindset than the traditional relationship between public administrations on the one side, mandating a scientific study to academics, and the researchers on the other, wishing to provide the best and more rigorous results as measured according to scientific standards. Instead, members of both communities shared a common vision of what was useful for both research and disaster management 


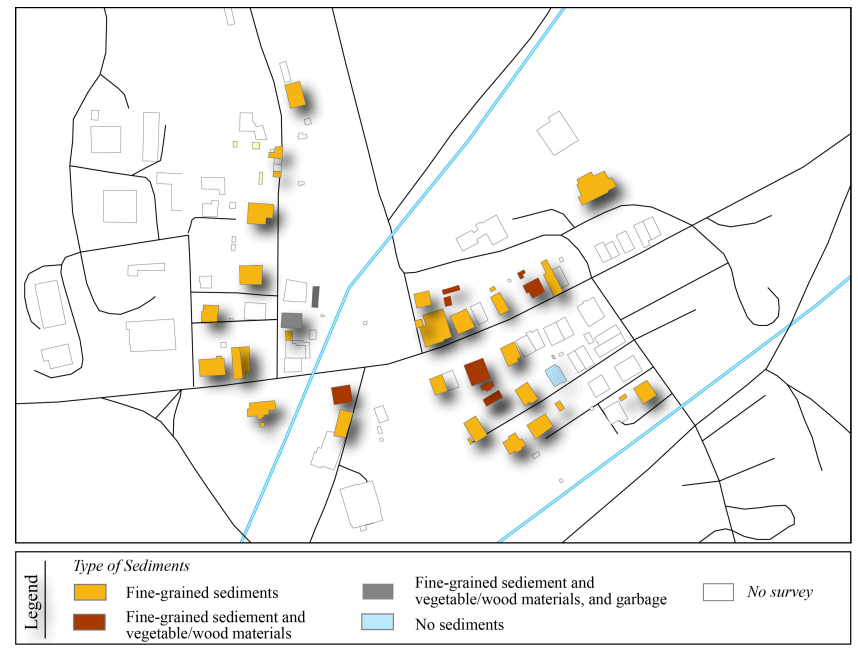

Fig. 6. Sediments in the surveyed buildings in Città della Pieve.

practices, putting on the same ground the different goals for which damage data collection is carried out (see De Groeve, 2013). This collaborative work was not triggered by one side that succeeded to engage the other, nor was the result of a new funding situation in which researchers were somehow obliged to be more responsive to public managers' needs (King, 2002). Rather it came as a natural consequence of shared experiences, the focus of which was relevant for both.

The current situation in Italy regarding damage data that can be used to comply with the requirements set by the EU Floods Directive and, more in general, to develop both preliminary and more in-depth risk assessment has been discussed in Sect. 2. At all levels, the available data limit the possibility of developing or validating flood damage functions so as to be able to estimate expected losses to physical assets in future events, and information on indirect damage is often lacking or provided in an excessively anecdotal form. As a result of the test carried out by a joint group of public administration officials and researchers, the requirement to develop a more effective procedure for collecting data in the aftermath of a flood has been recognised, in order to systematically address the need for georeferencing and the characterisation of both the hazardous event and the vulnerability of assets, which is so crucial for ex ante assessments. Our experience in the Umbria Region after the November 2012 flood not only represented a real test of the procedure, but also provided a basis for better-informed policy decisions for more resilient recovery and reconstruction.

The first "emergency" test of the newly developed forms for damage surveys conducted in the field on residences and certain businesses enabled us to improve the procedure further, also in terms of "investment" returns in comparison with the previous experiences of the same public administration. Apart from concluding the current work, and producing a final post-event, complete event scenario report, our purpose is to identify a framework that would represent a more exportable "standard" for other Italian regions.
This, of course, requires that we present the work to the National Department of Civil Protection and to officials from other regions, starting with Sicily, which was involved in the first trial. This effort to extend the procedure to other Italian regions may benefit from a closer connection with the insurance industry. Although insurance coverage of natural disasters has not been available in Italy until now, the current crisis and European pressures will force Italy to move towards a more financially sustainable way to compensate disaster victims. It may therefore be a good idea to share the development of this procedure with insurance companies as well. In fact, an interesting recent study by André et al. (2013) in France using insurance data has shown that there are also many errors in the way insurance companies collect data for compensating insured victims. Rather interestingly, the researchers found that out of 4000 damage records available for the Johanna and Xinthia storms, only 358 could actually be used for assessing the cost of coastal flood damage to residential buildings. This ratio between existing damage records and ones that are actually usable is not very different from the one we found in our own trial, as described in Sect. 2.

A second research priority that has been identified relates to the need to develop an ICT system to facilitate and optimise data collection, storage and interpretation. The introduction of more reliable ICT tools should help prevent the loss of relevant data, which is more frequent than one might imagine, particularly in the transition phase between the first emergency and the first recovery (Comerio, 1996). Data and information are often lost or poorly transferred during the shift between the authorities and agencies responsible for the two phases. In Italy, for example, the regional or national civil protection agencies hand over to the regular municipal and provincial administrations, which are responsible for the recovery phase. The interoperability and coordination of data among different agencies and administrations can certainly be eased by new technologies. However, without a clear understanding of what needs to be achieved, and what procedures and what processes must be followed, however, the misuse of ICT may be counterproductive. In fact, the type of IT platform that needs to be planned should perform a set of distinct and yet interconnected activities, ranging from data collection in the field (through the use of tablets for example) to data acquired from remote sources (such as satellite or aerial photos), to data management for the production of maps and graphs representing the various types of damage in different forms, to a variety of sectors, at different phases of the event (considering the timescale). Once established, a variety of uses for data management and comparison among different events can be envisaged; however, the experience gained to date in recent events (2004 tsunami, Haiti) and particularly after the advent of Web 2.0 (Harvard Humanitarian Initiative, 2011) pinpoint the potential problems of IT, as well as its advantages. Significant challenges that have emerged include the production of usable damage and need assessments, the possibility of monitoring recovery, and the 
possible emergence of new damage, in order to adjust information to the specific and changing needs of a wide spectrum of actors.

Finally, another important direction for future research relates to the issue of scale: how the best use can be made of damage reports such as the one developed in the Umbria Region after the November 2012 flood so as to feed regional and national databases: that is, how to summarise the relevant data on both direct and indirect losses so as to facilitate preliminary assessments like the one required by Article 4 of the EU Floods Directive. Scaling up and down would seem to be a simpler task now that computer programs allow management of "big data" and heavy maps; from a conceptual point of view, however, deciding what is relevant or irrelevant, and at what scale and for what purpose, is still a challenge.

\section{Supplementary material related to this article is available online at http://www.nat-hazards-earth-syst-sci.net/14/901/2014/ nhess-14-901-2014-supplement.pdf.}

Acknowledgements. The authors gratefully acknowledge:

- Piero Colajanni (Università di Messina) for his suggestions on developing of the procedure and the form;

- Sandro Costantini (Head of the Monitoring and Forecasting Centre of the Umbria Region (CFD - Centro Funzionale Decentrato)) and his staff, both for supporting the entire research project and for their suggestions during the exercise in the Umbria Region and the real implementation after the November 2012 flood;

- Paolo Poggi (from the Province of Perugia) and his staff for their suggestions during the exercise in the Umbria Region;

- ANCI Umbria and the municipalities of Orvieto, Marsciano, and Citta della Pieve for their support during field surveys in November 2012;

- Claudio Margottini, world-renowned expert on natural hazards, and Director of the Municipal Civil Protection Authority in Orvieto;

- Lorenzo Paffumi and Giusy Ottomano for their help in data collection;

- Roberto Iraci (from the Municipality of Barcellona) for his suggestions during the exercise in the Sicily Region;

- Concetta Marletta (from the Civil Protection of Sicily) for her suggestions during the exercise in the Sicily Region;

- Lucia Legnani, Master's graduate, for her help in carrying out the surveys, and especially on the post-survey data management and GIS support

- All the volunteers who actively participated in the survey after the November 2012 flood.

Edited by: L. Bouwer

Reviewed by: N. Manojlovic and one anonymous referee

\section{References}

André, C., Monfort, D., Bouzit, M., and Vinchon, C.: Contribution of insurance data to cost assessment of coastal flood damage to residential buildings: insights gained from Johanna (2008) and Xynthia (2010) storm events, Nat. Hazards Earth Syst. Sci., 13, 2003-2012, doi:10.5194/nhess-13-2003-2013, 2013.

Baggio, C., Bernardini, A., Colozza, R., Corazza, L., Della Bella, M., Di Pasquale, G., Dolce, M., Goretti, A., Martinelli, A., Orsini, G. Papa, F., and Zuccaro G.: Field Manual for postearthquake damage and safety assessment and short term countermeasures (AeDES), JRC Technical and Scientific Reports, European Communities, 2007.

Cammerer, H., Thieken, A. H., and Lammel, J.: Adaptability and transferability of flood loss functions in residential areas, Nat. Hazards Earth Syst. Sci., 13, 3063-3081, doi:10.5194/nhess-133063-2013, 2013

Comerio, M.: Disaster Hits Home. New Policy for Urban Housing Recovery, University of California Press, 1996.

Cornwall, A. and Jewkes, R.: What is participatory research?, Social Sci. Medicine, 41, 1667-1676, 1995.

De Groeve, T., Poljansek, K., and Ehrlich, D.: Recording Disasters Losses: Recommendation for a European Approach, JRC Scientific and Policy Report, available at: http://publications.jrc.ec.europa.eu/repository/ bitstream/111111111/29296/1/lbna26111enn.pdf (last access: 21 March 2014), 2013.

Downton, M. W. and Pielke Jr., R. A.: How accurate are Disaster Loss Data? The Case of U.S. Flood Damage, Nat. Hazards, 35, 211-228, 2005.

Downton, M. W., Miller, J. Z. B., and Pielke Jr., R. A.: Reanalysis of U.S. National Weather Service Flood Loss Database, Nat Hazards Rev., 6, 13-22, 2005.

EU: Directive 2007/60/EU of the European Parliament and of the Council of 23 October 2007 on the assessment and management of flood risks, Official Journal of the European Union, 2007

European Commission - DG Environment: Technical support in relation to the implementation of the Floods Directive (2007/60/EC), A user guide to the floods reporting schemas, Report Ref: V5.0 June 2013.

FLOODsite: Report T09-06-01: Evaluating flood damages: guidance and recommendations on principles and methods, available at: http://www.floodsite.net/ (last access: 21 March 2014), 2007.

Freni, G., La Loggia, G., and Notaro, V.: Uncertainty in urban flood damage assessment due to urban drainage modelling and depthdamage curve estimation, Water Sci. Technol., 61, 2979-2993, 2010.

Guzzetti, F., Cardinali, M., and Reichenbach, P.: The AVI Project: A bibliographical and archive inventory of landslides and floods in Italy, Environ. Manage., 18, 623-633, 1994.

H. John Heinz III Center for Science, Economics, and the Environment: The Hidden Costs of Coastal Hazards: Implications for Risk Assessment and Mitigation, Island Press, 2000.

Hallegatte, S. and Przyluski, V.: The economics of natural disasters: concepts and methods, World Bank, Sustainable Development Network, Office of the Chief Economist, Washington, DC, 2010.

Handmer, J.: The chimera of precision: inherent uncertainties in disaster loss assessment, Int. J. Mass Emergencies Disasters, 20, 325-346, 2002. 
Handmer, J., Abrahams, J., Betts, R., and Dawson, M.: Towards a Consistent Approach to Disaster Loss Assessment across Australia, Austr. J. Emergency Manage., 20, 10-18, 2005.

Harvard Humanitarian Initiative, Disaster Relief 2.0: The Future of Information Sharing in Humanitarian Emergencies. Washington, D.C. and Berkshire, UK: UN Foundation \& Vodafone Foundation Technology Partnership, 2011.

Huizinga, H. J.: Flood damage functions for EU member states, A report for the JRC-European Commission, HKV Consultants June 2007.

Jongman, B., Kreibich, H., Apel, H., Barredo, J. I., Bates, P. D., Feyen, L., Gericke, A., Neal, J., Aerts, J. C. J. H., and Ward, P. J.: Comparative flood damage model assessment: towards a European approach, Nat. Hazards Earth Syst. Sci., 12, 3733-3752, doi:10.5194/nhess-12-3733-2012, 2012.

Kelman, I. and Spence, R.: An overview of flood actions on buildings, Engineering Geology, 73, 297-309, 2004.

King, D.: Post disaster surveys: experience and methodology, Austr. J. Emergency Manage., 17, 39-47, 2002.

Kok, M., Huizinga, H. J., Vrouwenvelder, A. C. W. M., and Barendregt, A.: Standard Method 2004: damage and casualties caused by flooding, Road and Hydraulic Engineering Institute, Netherlands, 2005.

Ledoux, B.: Guide pour la Conduite des Diagnostics des Vulnérabilités aux Inondations pour les Entreprises Industrielles Rapport Final, Ministère de l'aménagement du territoire et de l'environnement, Direction de la prevention des pollutions et des risqué, Sous-direction de la prévention des risques majeurs, 2000.

Luino, F., Chiarle, M., Nigrelli, G., Agangi, A., Biddoccu, M., Cirio, C. G., and Giulietto, W.: A model for estimating flood damage in Italy: preliminary results, in: Environmental Economics and Investment Assessment, edited by: Aravossis, K., Brebbia, C. A., Karakas, E., and Kungolos, A. G., WIT Press, Southampton, 2006.

Maccaferri, S., Cariboni, F., and Campolongo, F.: Natural Catastrophes: Risk relevance and Insurance Coverage in the EU, JRC Scientific and Technical Reports, 2012.

Margottini, C., Delmonaco, G., and Ferrara, F.: Impact and Losses of Natural and Na-Tech Disasters in Europe, in: Inside Risk, Strategies for sustainable risk mitigation, edited by: Menoni, S. and Margottini, C., Springer, 2011.

Mercer, J., Kelman, I., Lloyd, K., and Suchet-Pearson, S.: Reflections on use of participatory research for disaster risk reduction, Area, 40, 172-183, 2008.

Merz, B., Kreibich, H., Thieken, A., and Schmidtke, R.: Estimation uncertainty of direct monetary flood damage to buildings, Nat. Hazards Earth Syst. Sci., 4, 153-163, doi:10.5194/nhess-4-1532004, 2004.
Merz, B., Kreibich, H., Schwarze, R., and Thieken, A.: Review article "Assessment of economic flood damage", Nat. Hazards Earth Syst. Sci., 10, 1697-1724, doi:10.5194/nhess-10-16972010, 2010.

Ministère de l'aménagement du territoire et de l'environnement: Risque Inondation: quels défis pour la recherche en appui à l'action publique, Collection "RéférenceS" de la Direction de la recherche et de l'innovation (DRI) du Commissariat Général au Développement Durable (CGDD), 2012.

Meyer, V., Becker, N., Markantonis, V., Schwarze, R., van den Bergh, J. C. J. M., Bouwer, L. M., Bubeck, P., Ciavola, P., Genovese, E., Green, C., Hallegatte, S., Kreibich, H., Lequeux, Q., Logar, I., Papyrakis, E., Pfurtscheller, C., Poussin, J., Przyluski, V., Thieken, A. H., and Viavattene, C.: Review article: Assessing the costs of natural hazards - state of the art and knowledge gaps, Nat. Hazards Earth Syst. Sci., 13, 1351-1373, doi:10.5194/nhess-13-1351-2013, 2013.

Pielke, Jr., R. A.: Flood Impacts on Society: Damaging Floods as a Framework for Assessment, in: Floods, edited by: Parker, D. Routledge Press, London, 2000.

Posner, L. P.: The pracademic: an agenda or re-engaging practitioners and academics, Public Budgeting and Finance, 29, 12-26, 2009.

Rose, A.: Economic Principles, Issues, and Research Priorities of Natural Hazard Loss Estimation, in: Modeling of Spatial Economic Impacts of Natural Hazards, edited by: Okuyama, Y. and Chang, S., Heidelberg, Springer, 2004.

Thieken, A. H., Olschewski, A., Kreibich, H., Kobsch, S., and Merz, B.: Development and evaluation of FLEMOps - a new Flood Loss Estimation Model for the private sector, in: Flood recovery, innovation and response, edited by: Proverbs, D., Brebbia, C. A., and Penning-Rowsell, E., WIT Press, Southampton, UK, 2008.

USACE: Generic depth-damage relationships for residential structures with basements, economic guidance memorandum (EGM) 04-01, available at: http://planning.usace.army. mil/toolbox/library/EGMs/egm04-01.pdf (last access: 21 March 2014), 2003.

Webb, G. R., Tierney, K. J., and Dahlhamer, J. M.: Businesses and disasters: Empirical patterns and unanswered questions, Nat. Hazards Rev., 1, 83-90, 2000.

Weichelsgartner, J. and Obersteiner, M.: Knowing sufficient and applying more: challenges in hazard management, Environ. Hazards, 4, 73-77, 2002.

Wergerdt, J. and Mark, S. S.: Post-Nargis Needs assessment and monitoring, ASEAN's Pioneering Response, Final report, Asean Secretariat, 2010.

World Meteorological Organisation (WMO): Conducting flood loss assessment. A tool for integrated flood management, APFM Technical Document n.7, Flood Management Tools Series, WMO, 2007. 